\title{
Plasmid-mediated quinolone resistance determinant qnrB19 in non- typhoidal Salmonella enterica strains isolated in Venezuela
}

\author{
Fanny Gonzalez ${ }^{1}$, Lucia Pallecchi ${ }^{2}$, Gian M. Rossolini ${ }^{2,3}$ and María Araque ${ }^{1}$ \\ ${ }^{1}$ Laboratorio de Microbiología Molecular, Facultad de Farmacia y Bioanálisis, Universidad de Los Andes, Mérida, \\ Venezuela \\ ${ }^{2}$ Dipartimento di Biotecnologie, Sezione di Microbiologia, Università di Siena, Siena, Italy \\ ${ }^{3}$ Dipartimento di Emergenza, Urgenza e dei Servizi Diagnostici, U.O. Microbiologia e Virologia, Azienda \\ Ospedaliera-Universitaria Senese, Siena, Italy
}

Key words: qnrB19; Salmonella; Venezuela

J Infect Dev Ctries 2012; 6(5):462-464.

(Received 14 February 2012 - Accepted 19 April 2012)

Copyright (C) 2012 Gonzalez et al. This is an open-access article distributed under the Creative Commons Attribution License, which permits unrestricted use, distribution, and reproduction in any medium, provided the original work is properly cited

Quinolone resistance in Enterobacteriaceae is typically mediated by chromosomal mutations leading to alterations in the target enzymes DNA gyrase and topoisomerase IV, or changes in drug entry and efflux. However, three plasmid-mediated quinolone resistance (PMQR) mechanisms conferring decreased susceptibility to quinolones (including some fluoroquinolones) have been recently described: QepA and OqxAB effluxes, Aac $\left(6^{\prime}\right)-\mathrm{Ib}-\mathrm{cr}$ aminoglycoside acetyltransferase and Qnr proteins ( $q n r A, q n r B, q n r C, q n r D$ and $q n r S)$ [1,2]. Although plasmid-mediated quinolone resistance of Qnr type has been identified in Enterobacteriaceae from the United States, Europe, and Asia [1,2], little is known about the diversity, type or range of $q n r$ genes in Latin America [3-6], especially in Venezuela. Therefore, the objective of this study was to screen for the presence of PMQR genes in non-typhoidal Salmonella enterica (NTS) strains with reduced susceptibility to fluoroquinolones, from clinical samples and chicken meat in Venezuela.

A total of 127 NTS strains belonging to the collection of the Molecular Microbiology Laboratory of the Pharmacy Faculty of University of the Andes (Mérida, Venezuela), were enrolled in this study. These included 117 strains from stool specimens of pediatric patients collected from 2005 to 2007 and 10 isolates recovered from raw chicken meat in 2008 . Six $(4.7 \%)$ of these isolates showed a typical phenotype with reduced resistance to ciprofloxacin
(MICs: $0.5-1 \mu \mathrm{g} / \mathrm{mL}$ ) and with affiliated susceptibility to nalidixic acid (MICs: $4-8 \mu \mathrm{g} / \mathrm{mL}$ ). These isolates were screened for extended-spectrum beta-lactamase (ESBL) phenotype, using cefotaxime and ceftazidime with and without clavulanic acid per Clinical and Laboratory Standards Institute (CLSI) guidelines [7] and confirmed by polymerase chain reaction (PCR) using specific primers for $b l a_{\text {TEM }}$, $b l a_{\mathrm{SHV}}$ and group bla ${ }_{\mathrm{CTX}-\mathrm{M},}$ [8]. Presence of $q n r A$, $q n r B, q n r S$, qnrD, aac(6')-Ib and qepA genes was screened by multiplex and simplex PCR amplifications, using primers and conditions previously described $[9,10]$. In addition, mutations in quinolone resistance-determining regions (QRDR) of the gyrA, gyrB and parC genes were also determined [11]. Amplicons were sequenced to determine the gene variants and mutations.

Regardless of origin and serovar, the $q n r B$ gene was detected in six Salmonella strains. Sequence analysis of the amplification product revealed the qnrB19 variant (Table). No mutations were identified in the QRDR of the gyrA, gyrB and parC genes [11]. In four of these strains the presence of ESBLs was suspected from ceftazidime or cefotaxime resistance (MICs: $64->256 \mu \mathrm{g} / \mathrm{mL}$ ) and by reestablishing the susceptibility in the presence of clavulanic acid (4 $\mu \mathrm{g} / \mathrm{mL}$ ) [7]. PCR amplification, using specific primers for $b l a_{\mathrm{TEM}}, b l a_{\mathrm{SHV}}$ and group $b l a_{\mathrm{CTX}-\mathrm{M}}$ [11], followed by sequencing analysis, allowed us to identify $b l a_{\mathrm{TEM}-1}+b l a_{\mathrm{SHV}-12}$ in $S$. Give LMM96 and 
Table. Characteristics of Salmonella serovar isolates harboring $q n r$ and $\beta$-lactamase genes

\begin{tabular}{|c|c|c|c|c|c|c|c|c|c|c|c|}
\hline \multirow{2}{*}{$\begin{array}{l}\text { Isolate } \\
\text { Number }\end{array}$} & \multirow{2}{*}{$\begin{array}{c}\text { Year of } \\
\text { collection }\end{array}$} & \multirow[t]{2}{*}{ Serovar } & \multirow[t]{2}{*}{ Sample } & \multicolumn{5}{|c|}{ MIC $\mu \mathrm{g} / \mathrm{mL}$} & \multirow{2}{*}{$\begin{array}{c}\text { qur } \\
\text { gene }\end{array}$} & \multirow{2}{*}{$\begin{array}{c}\beta- \\
\text { lactamase }\end{array}$} & \multirow{2}{*}{$\begin{array}{l}\text { PFGE } \\
\text { Profile }\end{array}$} \\
\hline & & & & CIP & NAL & CTX & CAZ & CTX/CLA & & & \\
\hline LMM46 & 2006 & Havana & Human & 1 & 4 & 0.25 & 2 & - & $q n r B 19$ & - & $\mathrm{C}$ \\
\hline LMM96 & 2006 & Give & Human & 1 & 8 & 4 & 32 & 0.125 & $q n r B 19$ & $\begin{array}{l}\text { bla }_{\mathrm{TEM}-1} \\
\text { bla }_{\mathrm{SHV}-12}\end{array}$ & A1 \\
\hline LMM183 & 2007 & Give & Human & 1 & 4 & 128 & 32 & 0.25 & $q n r B 19$ & $\begin{array}{c}b^{b l a_{\mathrm{TEM}-1}} \\
\text { bla }_{\mathrm{CTXM}-2}\end{array}$ & A2 \\
\hline LMM175 & 2008 & Heidelberg & Chicken & 0.5 & 8 & $>256$ & 32 & 1 & $q n r B 19$ & $\begin{array}{c}b l a_{\mathrm{TEM}-1} \\
b l a_{\mathrm{CTXM}-2}\end{array}$ & B1 \\
\hline LMM179 & 2008 & Heidelberg & Chicken & 1 & 4 & $>256$ & 32 & 0.5 & $q n r B 19$ & $\begin{array}{c}b l a_{\text {TEM-1 }} \\
b l a_{\text {CTXM-2 }}\end{array}$ & B2 \\
\hline LMM300 & 2008 & Meleagridis & Chicken & 0.5 & 4 & 0.25 & 1 & - & $q n r B 19$ & - & $\mathrm{D}$ \\
\hline
\end{tabular}

MIC: minimal inhibitory concentration; CIP: ciprofloxacin; NAL: nalidixic acid; CTX: cefotaxime; CAZ: ceftazidime; CTX/CLA: cefotaxime/clavulanic acid.

bla $a_{\mathrm{TEM}-1}+$ bla $_{\mathrm{CTX}-\mathrm{M}-2}$ in the other three strains: $S$. Give LMM183, $S$. Heidelberg LMM175 and $S$. Heidelberg LMM179 (Table). Association between QnrB-like determinants and ESBLs has been previously reported $[2-4,6]$.

Qnr-positive plasmids were successfully transferred by transformation from serovars Salmonella to E. coli HB101. Transformants designated as LMM46-T, LMM96-T, LMM183-T, LMM175-T, LMM179-T and LMM300-T, could be selected on Mueller Hinton Agar plates supplemented with $0.06 \mu \mathrm{g} / \mathrm{ml}$ ciprofloxacin. PCR and sequencing confirmed the presence of qnrB19 in the transformants obtained. Susceptibility testing showed that the MICs of ciprofloxacin and nalidixic acid for all transformants were similar to corresponding host strains. Plasmid DNA was purified from transformants by an alkaline lysis method [12]. Electrophoresis showed the presence of a $\sim 17 \mathrm{~kb}$ plasmid with a similar restriction pattern, using the PstI enzyme (Promega, Madison, WI, USA) in all the transformants obtained.

All qnr-positive isolates were typed using PFGE [13]. In total, four PFGE clusters were identified (AD) and isolates of different serotypes were clustered separately. Similar distribution patterns have also been observed in NTS isolates with reduced susceptibility to ciprofloxacin from infants in Wuhan, China [14].
This result indicates that the horizontal transfer PMQR occurs, since the same plasmid profile was observed in strains from different origins, times, and serovars. Fluoroquinolones are widely used in veterinary medicine as well as in poultry production, and $q n r$-positive NTS isolates could be selected and transmitted to humans through the food chain.

As far as the authors know, this is the first description of the occurrence of the qnrB19 gene in NTS isolates from pediatric patients and chicken meat in Venezuela. Isolates similar to those described in this study may be hard to identify in clinical laboratories since this phenotype is difficult to recognize by conventional methods. In addition, the $q n r B 19$ gene found in enteropathogens, classified as susceptible to fluoroquinolones, may promote further selection from low- to high-level resistance when fluoroquinolones are used. Hence it is necessary to increase the sensitivity and optimize the screening procedures when strains that might contain such resistance determinants are studied.

\section{Acknowledgments}

This study was conducted within the research activities of the Bacterialnet project, ALFA II Contract No II-531-FCFA-FCD-FI, and partially supported by Consejo de Desarrollo Científico, Humanístico y Tecnológico (CDCHT-ULA) of University of the Andes, MéridaVenezuela (grant CVI-ADG-FA-02-97). 


\section{References}

1. Strahilevitz J, Jacoby GA, Hooper DC, Robiseck A (2009) Plasmid-mediated quinolone resistance: a multifaceted threat. Clin Microb Rev 22: 664-689.

2. Robicsek A, Jacoby GA, Hooper DC (2006) The worldwide emergence of plasmid-mediated quinolone resistance. Lancet Infect Dis 6: 629-640.

3. Pallecchi L, Riccobono E, Mantella A, Bartalesi F, Sennati S, Gamboa H, Gotuzzo E, Bartoloni A, Rossolini GM (2009) High prevalence of $q n r$ genes in commensal enterobacteria from healthy children in Peru and Bolivia. Antimicrob Agents Chemother 53: 2632-2635.

4. Escobar A, PortoA, Joris R, Sansevich ME, Gutkind G, Di Conza J, Truppia LA (2010) Detección de genes $q n r$ en aislamientos de enterobacterias con resistencia simultánea a fluorquinolonas y oximinocefalosporinas. Revista FABICIB 14: 39-45.

5. Ferrari R. Galiana A, Cremades R, Rodríguez JC, Magnani M, Tognim MCB, Oliveira T, Royo G (2011) Plasmidmediated quinolone resistance by genes qnrAl and qnrB19 in Salmonella strains isolated in Brazil. J Infect Dev Ctries 5: 496-498.

6. García-Fulgueiras V, Bado I, Mota MI, Robino L, Cordeiro NF, Varela A, Algorta G, Gutkind G, Ayala JA, Vignoli R (2011) Extended-spectrum $\beta$-lactamases and plasmidmediated quinolone resistance in enterobacterial clinical isolates in the paediatric hospital of Uruguay. J Antimicrob Chemother 66: 1725-1729.

7. Clinical and Laboratory Standards Institute (2011) Performance standards for antimicrobial susceptibility testing, 21th informational supplement. Document M100S20. Clinical and Laboratory Standards Institute (CLSI).Wayne, PA.

8. Pallecchi L, Bartoloni A, Fiorelli C, Mantella A, Di Maggio T, Gamboa H, Gotuzzo E, Kronvall G, Paradisi F, Rossolini GM (2007) Rapid dissemination and diversity of CTX-M extended-spectrum $\beta$-lactamase genes in commensal Escherichia coli isolates from healthy children from low- resource settings in Latin America. Antimicrob Agents Chemother 51: 2720-2725.

9. Cattoir V, Weill FX, Poirel L, Fabre L, Soussy CJ, Nordmann P (2007) Prevalence of qnr genes in Salmonella in France. J Antimicrob Chemother 59: 751-754.

10. Yamane K, Wachino J, Suzuki S, Arakawa Y (2008) Plasmid-mediated qepA gene among Escherichia coli clinical isolates from Japan. Antimicrobial Agents Chemother 52: 1564-1566.

11. Eaves DJ, Randall L, Gray DT, Buckley A, Woodward MJ, White AP, Piddock LJV (2004) Prevalence of mutations within the quinolone resistance-determining region of gyr $A$, $\operatorname{gyr} B, \operatorname{par} C$, and $\operatorname{parE}$ and association with antibiotic resistance in quinolone-resistance Salmonella enterica. Antimicrob Agents Chemother 48: 4012-4015.

12. Birnboim HC, Doly J (1979) A rapid alkaline extraction procedure for screening recombinant plasmid DNA. Nucleic Acid Res 7: 1513-1523.

13. Ribot EM, Fair MA, Gautom R, Cameron DN, Hunter SB, Swaminathan B, Barrett TJ (2006) Standardization of pulsed-field gel electrophoresis protocols for the subtyping of Escherichia coli O157:H7, Salmonella, and Shigella for PulseNet. Foodborne Pathog Dis 3: 59-67.

14. Cui S, Li J, Sun Z, Hu C, Jin S, Li F, Guo Y, Ran L, Ma Y (2009) Characterization of Salmonella enterica isolates from infants and toddlers in Wuhan, China. J Antimcrob Chemother 63: 87-94.

\section{Corresponding author}

María Araque

Laboratorio de Microbiología Molecular

Departamento de Microbiología y Parasitología

Facultad de Farmacia y Bioanálisis

Universidad de Los Andes, Sector Campo de Oro

Mérida 5101, Venezuela

Telephone/Fax: 0058-274-2403180

Email: araquemc@ula.ve

Conflict of interests: No conflict of interests is declared. 